\title{
PHARMACOLOGICAL PROPERTIES OF ISOLATED HORIZONTAL AND BIPOLAR CELLS FROM THE SKATE RETINA ${ }^{1}$
}

\author{
ERIC M. LASATER, ${ }^{*, 2}$ JOHN E. DOWLING, $\ddagger$ AND HARRIS RIPPS $\ddagger \S$ \\ *Department of Cellular and Developmental Biology, Harvard University, Cambridge, Massachusetts 02138, $\ddagger$ Marine Biological \\ Laboratory, Woods Hole, Massachusetts 02543, and \$Department of Ophthalmology and Physiology and Biophysics, New York \\ University School of Medicine, New York, New York 10016
}

Received July 22, 1983; Revised December 7, 1983; Accepted February 3, 1984

\begin{abstract}
Retinal neurons were enzymatically and mechanically dissociated from adult skate retinas and maintained in cell culture for up to 14 days. Intracellular recordings were made from isolated horizontal and bipolar cells while neurotransmitters were applied via pressure ejection. L-Glutamate, quisqualate, kainate, and $\gamma$-aminobutyric acid (GABA), when applied to horizontal cells, produced large (60 to $70 \mathrm{mV}$ ), long-lasting depolarizations. These responses appear to consist of at least two components: a graded depolarization and a $\mathrm{Ca}^{++}$ dependent regenerative component. As regards bipolar cells, L-glutamate and its analogues depolarized about $30 \%$ of the cells tested, while GABA hyperpolarized most of these neurons. Both agents acted on bipolar cells by increasing conductance. Repeated applications of $\mathbf{L}$-glutamate, quisqualate, kainate, and GABA to horizontal cells produced no desensitization, but in these circumstances the glutamate analogues, kainate and quisqualate, induced certain morpholngical changes, most notably a retraction of cell processes and the appearance of blebs on the cell surface.
\end{abstract}

The identity of the photoreceptor transmitter in the vertebrate retina is still uncertain, although there is convincing evidence that the transmitter is released in darkness and exerts an excitatory (i.e., depolarizing) effect on horizontal cells (Trifonov, 1968; Dowling and Ripps, 1972; Ripps et al., 1974, 1976). The acidic amino acids, glutamate and aspartate, are strong candidates for this role since both have been shown to depolarize horizontal cells and to mimic in other ways the action of the natural transmitter (Cervetto and MacNichol, 1972; Murakami et al., 1972; Dowling and Ripps, 1973; Kaneko and Shimazaki, 1976; Wu and Dowling, 1978).

Despite these observations, the view that either glutamate or aspartate serves as the photoreceptor transmitter has been seriously challenged (cf. Shiells et al., 1981), based largely on the fact that, when applied to the retina, relatively high (millimolar) concentrations are required for the effects to be manifest. But it is important to recall that the vertebrate retina contains effective uptake mechanisms for the acidic amino acids (Tunnicliff, 1975; Marc and Lam, 1981), and there is the likelihood that such mechanisms markedly reduce the apparent efficacy of these agents. Indeed, it has been shown recently that inhibiting glutamate uptake by pre-incubation in D-aspartate significantly potentiates the effect of L-glutamate on carp horizontal cells (Ishida and Fain, 1981; Ishida, 1982). Thus, it is clearly desirable to seek alternative methods for studying the

\footnotetext{
${ }^{1}$ We thank Stephanie T.evinson for typing the manuscript and Patricia Sheppard for preparing the figures. This work was supported by Grants EY05476 (E. M. L.), EY00824 (J. E. D.), and EY00285 (H. R.) from the National Institutes of Health.

${ }^{2}$ To whom correspondence should be addressed.
}

relative effectiveness of putative transmitters on target cells (Ariel et al., 1983).

An approach that obviates the dilution problem associated with uptake mechanisms involves recording the intracellular responses of isolated, identifiable cells maintained in culture to test solutions pressure ejected from pipettes in their immediate vicinity. This procedure has been used to examine the conductance mechanisms of brain and spinal cord neurons (MacDonald and Wojtowicz, 1980, 1982; Wojtowicz et al., 1981) and more recently to study the pharmacological properties of the cone-driven $\left(\mathrm{H}_{1}\right)$ horizontal cells of the carp retina (Lasater and Dowling, 1982, Lasater et al., 1983). In the present paper, we report studies performed with pressure ejection techniques on primary cultures of horizontal and bipolar cells enzymatically isolated from the skate retina. The results from the allrod retina of the skate (Dowling and Ripps, 1970; Szamier and Ripps, 1983) provide an interesting comparison with those obtained from the cone-driven horizontal cells of carp, and may prove useful in establishing the identity of the rod neurotransmitter.

\section{Materials and Methods}

Cell dissociation. Retinas were removed from light-adapted skates (Raja oscellata and Raja erinacea) and were incubated in a modified tissuc culture medium containing $3 \mathrm{mg} / \mathrm{ml}$ of papain (Worthington Biochemicals Co., Freehold, NJ) preactivated with $60 \mu \mathrm{M}$ cysteine. To maintain normal osmolarity, the culture medium (L-15, GIBCO) was supplemented with $102 \mathrm{~mm} \mathrm{NaCl}, 350 \mathrm{~mm}$ urea, $5.5 \mathrm{~mm}$ glucose, and $\mathrm{pH}$ was adjusted to 7.8 . After $30 \mathrm{~min}$ of incubation, the retinas were washed twice in $5 \mathrm{ml}$ of the modified L-15 and placed in the first of eight plastic tissue culture dishes (Corning Glass Works, Corning, NY).

To obtain single cells, the retinas were disrupted by repeated passage 
through a Pasteur pipette as they were transferred through the culture dishes. The last four dishes contained the greatest number of isolated neurons and were stored for 2 to 14 days in an incubator at 16 to $20^{\circ} \mathrm{C}$. Every other day 250 units $/ \mathrm{ml}$ of penicillin and $250 \mathrm{mcg} / \mathrm{ml}$ of streptomycin were added to each culture dish to inhibit bacterial growth.

Intracellular recording. Prior to each experiment, the culture medium was replaced with elasmobranch Ringer's solution consisting of 250 $\mathrm{mM} \mathrm{NaCl}, 6 \mathrm{mM} \mathrm{KCl}, 20 \mathrm{mM} \mathrm{NaHCO}$, $1 \mathrm{mM} \mathrm{MgCl}, 4 \mathrm{mM} \mathrm{CaCl}_{2}, 0.2$ $\mathrm{mM} \mathrm{NaH} 2 \mathrm{PO}_{4}, 360 \mathrm{mM}$ urea, $10 \mathrm{mM}$ glucose, and $5 \mathrm{mM}$ HEPES; the solution was equilibrated with $\mathrm{O}_{2}$ and adjusted to $\mathrm{pH} 7.6$ to 7.8 . With the culture dish mounted on the stage of an inverted microscope, cells were viewed under phase-contrast optics and impaled with microelectrodes carried on a conventional manipulator-microdrive unit (David Kopf Instruments, Tujunga, CA). The electrodes were filled with $4 \mathrm{M}$ KAc and usually had resistances of 100 to 200 megohms measured in Ringer's. Intracellular potentials were led to a unity gain amplifier (WP Instruments model 707, New Haven, CT) with low pass filtering (upper cutoff frequency at $3 \mathrm{kHz}$ ), amplified, viewed on an oscilloscope, and recorded on a Brush penwriter (Gould Instruments, Cleveland, $\mathrm{OH})$. To evaluate the input resistances of the cells, small constant current hyperpolarizing pulses ( 5 to $10 \mathrm{pA}$ ) were presented through a bridge circuit.

Drug-containing pipettes were fabricated by pulling fine-tipped micropipettes, breaking the ends, and beveling to give tip openings of 10 to $20 \mu \mathrm{m}$. Two triple-barrel ensembles, carried on separate micromanipulators, were filled with various test agents dissolved in Ringer's solution and positioned 150 to $250 \mu \mathrm{m}$ from a target cell. Drugs were ejected rapidly (in 0.5 to 1.0 -sec pulses) by means of a $0.2-\mathrm{ml}$ microsyringe (Gilmont Instruments, Great Neck, NY). The standard volume in each drug pulse was typically $0.5 \mu \mathrm{l}$, and all concentrations reported are those in the drug pipettes. However, with this form of drug delivery we estimate, based on calibration experiments employing applications of high $\mathrm{K}^{+}$Ringer's solution, that the test agent underwent approximately a $25 \%$ dilution before reaching the cell surface.

\section{Results}

\section{Horizontal and bipolar cells in culture}

Morphological observations. Freshly prepared cultures of skate horizontal cells resemble in essential details the in situ profiles seen in silver-impregnated (Golgi) tissue (J. E. Dowling and H. Ripps, unpublished observations). As shown in Figure $1 a$, the neurons have large cell bodies and a dendritic spread of 100 to $200 \mu \mathrm{m}$. Fine processes, that presumably contact the receptor terminals in the intact retina, can be observed extending from the stouter dendrites immediately after isolation (arrows, Fig. 1a). However, during the first $12 \mathrm{hr}$ in culture, the finer processes appear to withdraw into the larger dendrites, giving the cells a blunt, rounded appearance (Fig. 1b). This behavior is similar to that reported previously for carp horizontal cells, which retract their fine processes soon after isolation (Lasater and Dowling, 1982). Over a period of 3 to 4 days in culture, skate horizontal cells sprout new processes that remain for as long as the cells are viable (up to 21 days) (Fig. 1c).

Bipolar cells are also readily identified in culture since they retain their typical morphological characteristics after isolation. Most cells (cf. Fig. 1d) have a short, stout dendritic process emerging from the perikaryon that divides into two or three branches. These are divided, in turn, to form several slender branches from which numerous fine processes are often seen to emerge. The latter appear to be terminal endings, and only cells that displayed this feature were selected for study. The axon of the bipolar cells was present in most instances, and the bulbous synaptic terminals of the cells were usually observed. Unlike the situation with horizontal cells, the morphology of bipolar cells remained virtually unchanged during the culture period.

\section{Intracellular recordings from horizontal cells}

Intracellular recordings were made from more than 100 isolated horizontal cells maintained in culture for 1 to 14 days; no consistent differences in the cells' reactions to test sub- stances were observed as a function of time in culture. However, it is of interest to note the variations in resting potential that were recorded during the first few minutes after electrode penetration. Most often the potential dropped almost immediately to a resting level of -60 to $-80 \mathrm{mV}$, and the membrane potential as well as the cell's input resistance (500 megohms typically, but ranging from 100 to 800 megohms) remained relatively constant. Other cells gave only a small negativity when first impaled; but within 1 to $2 \mathrm{~min}$, the input resistance increased transiently, the membrane potential went through a period of instability, and the cell gradually hyperpolarized to a lower resting level. In addition, a small percentage of the cells which at first showed a small transmembrane potential (15 to $30 \mathrm{mV}$ ) did nol undergo further changes in resting potential despite a marked increase in input resistance (Fig. 2a). However, it was often possible in such cases to "induce" a lower resting potential with a brief application of Ringers' containing a high concentration of $\mathrm{KCl}$. The phenomenon is illustrated in Figure $2 a$, where a pulse of $150 \mathrm{mM} \mathrm{KCl}$ initially caused the cell to depolarize transiently and then to hyperpolarize slowly toward the final resting potential with a concomitant decrease in input resistance. Of the cells used in this study, about $80 \%$ had final resting membrane potentials between -70 and -80 $\mathrm{mV}$; the other cells used had resting potentials between -60 and $-70 \mathrm{mV}$.

Responses to test agents. The effects of various putative neurotransmitters and transmitter agonists were studied; the substances tested were $\mathrm{D}$ - and L-aspartate, $\mathrm{D}$ - and L-glutamate, $\gamma$-aminobutyric acid (GABA), glycine, quisqualate, D- and Lhomocysteic acid, L-cysteine sulfinic acid, $\alpha$-aminoadipic acid, carbachol, dopamine, kainic acid (KA), $N$-methyl-DL-aspartate, muscimol, kojic acid, and vasoactive intestinal peptide. Of these agents, only L-glutamate, GABA, and the glutamate agonists, kainate and quisqualate, produced consistent changes in the membrane potential of horizontal cells.

Typical responses to pulses of $\mathrm{L}$-glutamate and GABA are shown in Figure $2 b$. In each case, $100 \mu \mathrm{M}$ concentration of the drug resulted in a rapid depolarization to $0 \mathrm{mV}$, after which the cell's input resistance appeared to increase and its membrane potential began to hyperpolarize slowly. However, after remaining for 30 to $60 \mathrm{sec}$ near the peak of the response, the membrane potential dropped precipitously, either to an intermediate value 20 to $40 \mathrm{mV}$ above the resting level (Fig. $2 b$ ) from which it slowly returned to the resting potential, or close to its resting level (Fig. 2, $c$ and $d$ ); at this stage the input resistance had also decreased to its prestimulus value. The similarities in the responses to L-glutamate and GABA suggest that they may be mediated by similar ionic mechanisms.

Skate horizontal cells were also depolarized by the glutamate agonists quisqualate and kainic acid, both of which induced responses similar to those evoked by L-glutamate and GABA. It was generally the case that the efficacy of these drugs was in the order: $\mathrm{KA} \geq$ quisqualate $>\mathrm{GABA} \geq$ glutamate, with threshold concentrations for kainate and L-glutamate being approximately $10 \mu \mathrm{M}$ and $20 \mu \mathrm{M}$, respectively. Interestingly, the GABA agonists, muscimol and kojic acid, were without effect on skate horizontal cells. As shown in Figure $2 d$, a cell responsive to GABA $(100 \mu \mathrm{M})$ and quisqualate $(50 \mu \mathrm{M})$ was unaffected by 500 $\mu \mathrm{M}$ pulses of either of these drugs.

Other transmitter candidates or their agonists were entirely without effect on the horizontal cells when applied in concentrations $<1 \mathrm{mM}$. A few examples are shown in Figure $2 c$, where the results obtained with $200 \mu \mathrm{M}$ carbachol, L-aspartate, and glycine are compared with the potential change elicited by a comparable concentration of L-glutamate. L-Aspartate was tested at concentrations as high as $20 \mathrm{mM}$, and in a small percentage of cells (10 to $20 \%$ ) depolarizing responses were observed when the concentration of this agent exceeded $5 \mathrm{mM}$ 

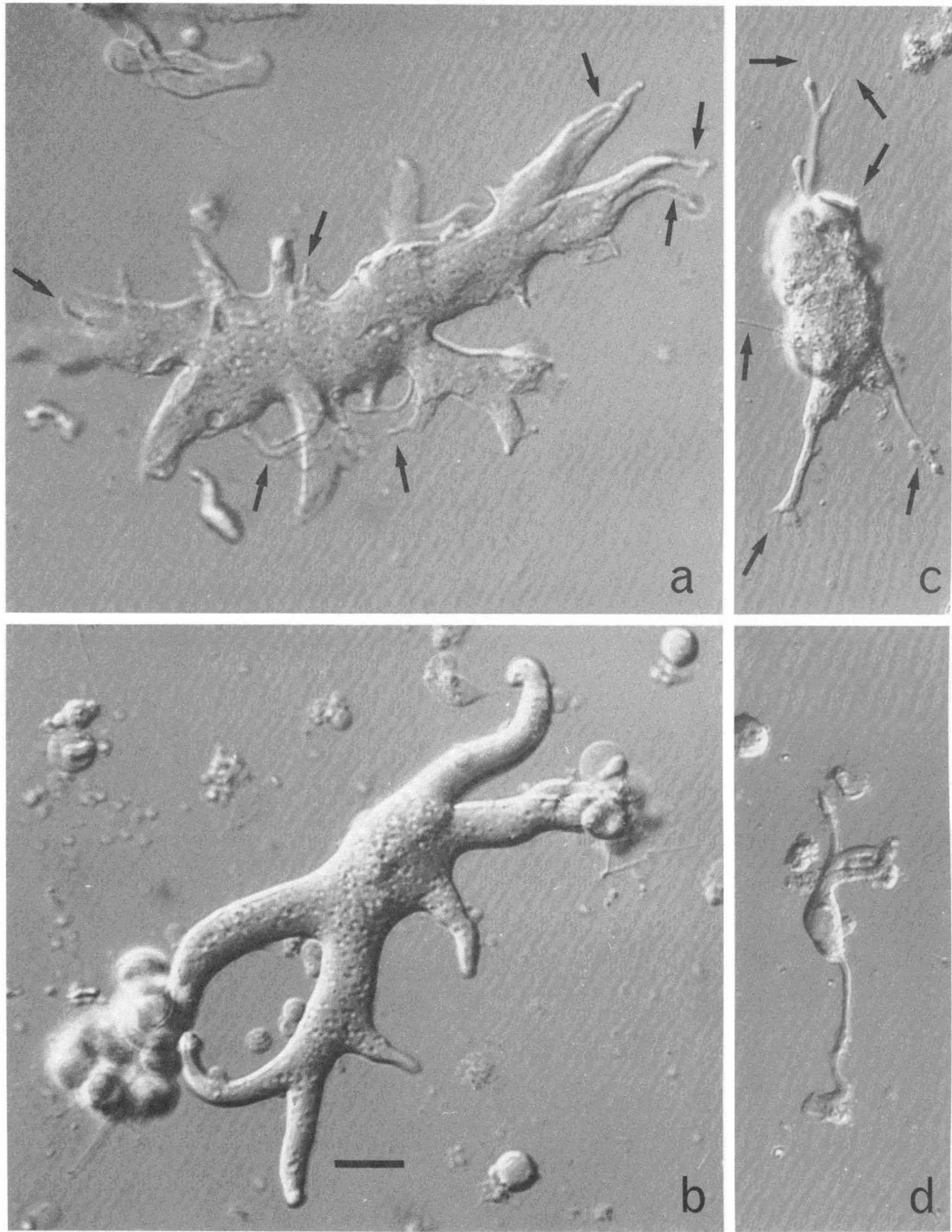

Figure 1. Isolated cells of the skate retina. $a$, Freshly isolated horizontal cell showing fine processes (arrows). $b$, Horizontal cell after 24 hr in culture. Note that the fine processes have retracted and the dendrites have a rounded, blunt appearance. $c$, Cell in culture for 6 days. Three large processes have emerged from an oval cell body. At the ends of the large processes and also extending from the cell body are several small, fine processes (arrows), d, A bipolar cell in culture for $24 \mathrm{hr}$. The calibration bar is $20 \mu \mathrm{m}$. 


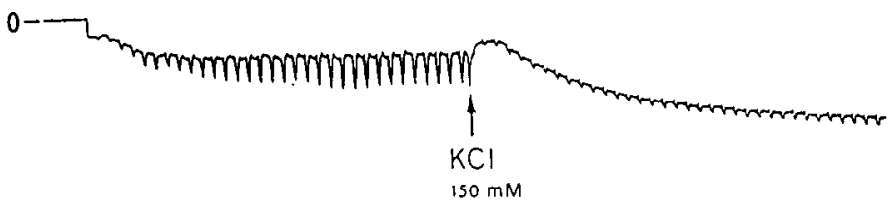

b

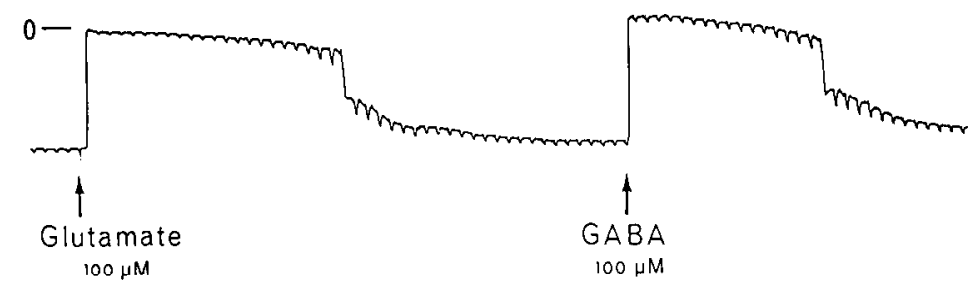

Figure 2. Intracellular recordings from isolated horizontal cells in response to $\mathrm{K}^{+}$and various transmitters and agonists. $a$, Following electrode penetration, this cell had a small resting membrane potential which remained at the same level despite a significant increase in input resistance. Application of a pulse of $150 \mathrm{~mm} \mathrm{~K}{ }^{+}$depolarized the cell, reduced the input resistance, and induced a slow hyperpolarization of the membrane potential which reached a final resting level of $-65 \mathrm{mV} . b$, Typical responses to L-glutamate and GAB $\Lambda$ exhibit a rapid depolarization to $0 \mathrm{mV}$ which was maintained for $>30$ sec. The potential then fell sharply to an intermediate level from which it returned to the resting level. The changes in amplitude of the current pulses indicate the variations in input resistance accompanying these events. $c$, Carbachol, glycine, and aspartate were without effects on these cells, but note the differences between the responses to L-glutamate and that evoked by a depolarizing current pulse; the latter gives rise to a larger overshoot and a shorter plateau phase than the drug response. $d$, The depolarizing response to GABA was not mimicked hy the GABA agonists, muscimol and kojic acid, but $50 \mu \mathrm{m}$ quisqualate, a glutamate agonist, produced a long-lasting depolarization. In this and in subsequent figures the recurrent hyperpolarizing deflections represent constant current pulses (5 to $10 \mathrm{pA}$ ) delivered throughout the recording period.

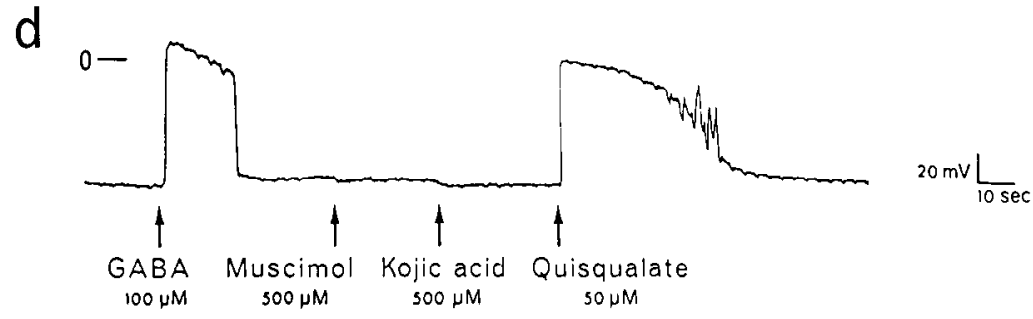

(Fig. $3 b$ ). Also shown in Figure $2 c$ is the response to a depolarizing current pulse, which illustrates the capacity of these cells to produce a regenerative response. Pulses exceeding threshold (Fig. 2c, small arrow) resulted in the discharge of a spike that overshot the zero mark by 20 to $30 \mathrm{mV}$. The transient depolarization was followed by a plateau phase at about $0 \mathrm{mV}$ that lasted 2 to $10 \mathrm{sec}$ before the potential fell to the resting level. Similar regenerative responses have been observed in recordings from isolated horizontal cells of goldfish (Tachibana, 1981) and catfish (Johnston and Lam, 1981; Shingai and Christensen, 1983b).

Response components. The drug-induced depolarizations in isolated skate horizontal cells are strikingly similar to those reported in the carp study (Lasater and Dowling, 1982), where it was shown that there are at least two components contributing to the response, an underlying graded depolarization followed by a prolonged regenerative response. We believe a similar situation holds for skate horizontal cells. However, we found that even with threshold drug concentrations, both response components were usually evoked, and it was difficult to observe one independently of the other. However, as shown in Figure 3, it was possible at times to elicit only a graded depo- larization from these cells. In this experiment, varying amounts of drug were applied to the cell by altering the volume of solutions expressed from a pipette containing a fixed concentration of L-glutamate $(1 \mathrm{~mm})$. The first pulse applied had a volume of $2.5 \mu \mathrm{l}$; subsequent applications delivered volumes of $3.0,3.5$, and $4 \mu \mathrm{l}$, respectively. The cell responded in a graded fashion to the first two applications of L-glutamate, but thereafter with maximum amplitude responses. Following the application of the 4- $\mu$ l pulse of drug-containing Ringer's, the response lasted very much longer than did the response elicited with the 3.5- $\mu$ l drug pulse. We found a similar lengthening of the response to occur when pulse volume remained constant but concentration of drug within the Ringer's was increased.

In the experiment shown in Figure $3 a$, no current pulses were applicd to the cell while drug applications were made. The shapes of the responses elicited with the larger volumes of drugcontaining Ringer's were very similar to those elicited by Lglutamate in experiments in which current pulses were applied through the recording pipette (see Fig. 2). These results appear to rule out the possibility that the current pulses significantly distorted the overall response waveform by, for example, activating or inactivating voltage-sensitive channels in these cells. 
a

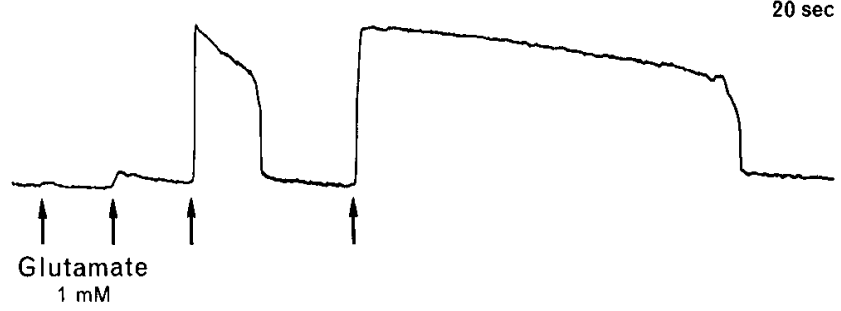

b

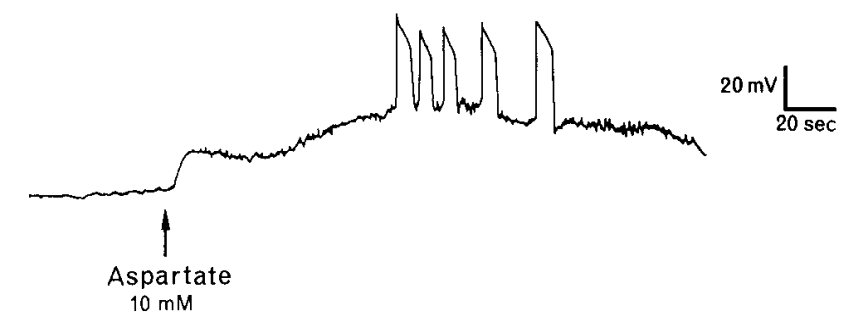

C

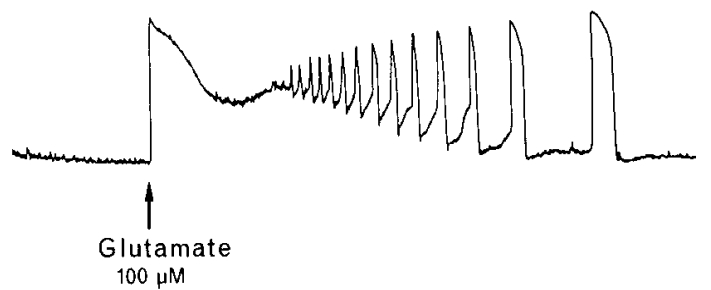

Figure 3. Responses and regenerative events observed in horizontal cells. $a$, Ringer's solution containing $1 \mathrm{mM}$ of L-glutamate was applied in four different volumes of $2.5,3.0,3.5$, and $4.0 \mu \mathrm{l}$. The cell responded in a graded fashion to the first two applications of the drug and in an "all or nothing" manner to the last two drug applications. Note the substantial increase in response duration with increases in the amount of agent applied. $b, 10 \mathrm{mM}$ L-aspartate caused the cell to depolarize slowly over a period of about $40 \mathrm{sec}$. At this point, five brief regenerative events occurred. $c$, After a glutamate-induced depolarization, numerous spikes occurred as the cell slowly hyperpolarized toward rest. Preceding several spikes, there can be seen a slow depolarization leading up to the threshold level for spike activation. For the cells whose response are shown in $b$ and $c$, the threshold for spike production was about a $30-\mathrm{mV}$ depolarization from the resting membrane potential.

In other experiments, it was possible occasionally to observe distinct regenerative events following drug application. Two such recordings, during which current pulses were not delivered, are shown in Figure $3, b$ and $c$. In Figure $3 b$ a high concentration $(10 \mathrm{mM})$ of L-aspartate produced a slow biphasic depolarization of about $30 \mathrm{mV}$, at which point five regenerative-like potentials occurred. Each was approximately the same amplitude and lasted for about $8 \mathrm{sec}$. A somewhat different sequence of events is shown in Figure $3 c$, where the horizontal cell was stimulated with a pulse of $100 \mu \mathrm{M} \mathrm{L}$-glutamate. After the usual large depolarizing response $(75 \mathrm{mV})$ to this agent, the membrane potential began to return to base line. However, as it ap proached an intermediate level the membrane depolarized slightly, and a number of regenerative events were triggered. Initially these were small and brief, but as the cell hyperpolarized further, they became larger and longer in duration, and the graded depolarization preceding each spike could be seen. Eventually, the membrane potential returned to its resting level, and no further regenerative events occurred (cf. MacDonald and Wojtowicz, 1982).

To determine whether $\mathrm{Ca}^{++}$is involved in the regenerative component of the responses of skate horizontal cells to Lglutamate and GABA, several experiments were performed with the cells bathed in a low $\mathrm{Ca}^{++}$-Ringer solution. Since prelimi- nary studies showed that isolated skate horizontal cells were unable to survive the complete absence of $\mathrm{Ca}^{++}$in the bathing Ringer solution, the $\mathrm{Ca}^{++}$concentration was reduced to 100 $\mu \mathrm{M}$. The results of one such experiment, illustrated in Figure $4 a$, show that the depolarizing response elicited by $100 \mu \mathrm{M}$ GABA is smaller in amplitude, and that the rising and falling phases of the response are much slower than in the normal $\mathrm{Ca}^{++}$control solution. In addition, there appears to be an increase in input resistance associated with the peak of the depolarizing potential. Low $\mathrm{Ca}^{++}$had similar effects on the responses to L-glutamate and its analogues (not shown). These findings suggest that in skate, as in carp, there are at least two components to the drug-induced horizontal cell response: a slow $\mathrm{Ca}^{++}$-insensitive graded potential and a regenerative, $\mathrm{Ca}^{++}$-mediated action potential.

The effects of antagonists. Various transmitter antagonists were tested for their ability to block the responses to GABA and to L-glutamate and its agonists; included in this group were the glutamate and aspartate antagonists $\mathrm{D}, \mathrm{L}-\alpha$-aminoadipic acid, D,L- $\alpha$-methyl glutamic acid, 2-amino-4-phosphonobutyric acid, and $\mathrm{L}$-glutamic acid diethyl ester, and the GABA antagonists bicuculline methochloride and baclofen (Lioresal).

In contrast to the results obtained in carp, where we found that $\mathbf{D}, \mathbf{L}-\alpha$-methyl glutamate blocked the responses to L-glutamate and its agonists, none of the glutamate antagonists were effective in altering the action of L-glutamate or GABA on skate horizontal cells. On the other hand, GABA responses were reversibly blocked by bicuculline. Figure $4 b$ shows that following the application of bicuculline, the depolarizing action of GABA was almost completely suppressed. However, after about $30 \mathrm{sec}$ a nearly maximal response of relatively brief
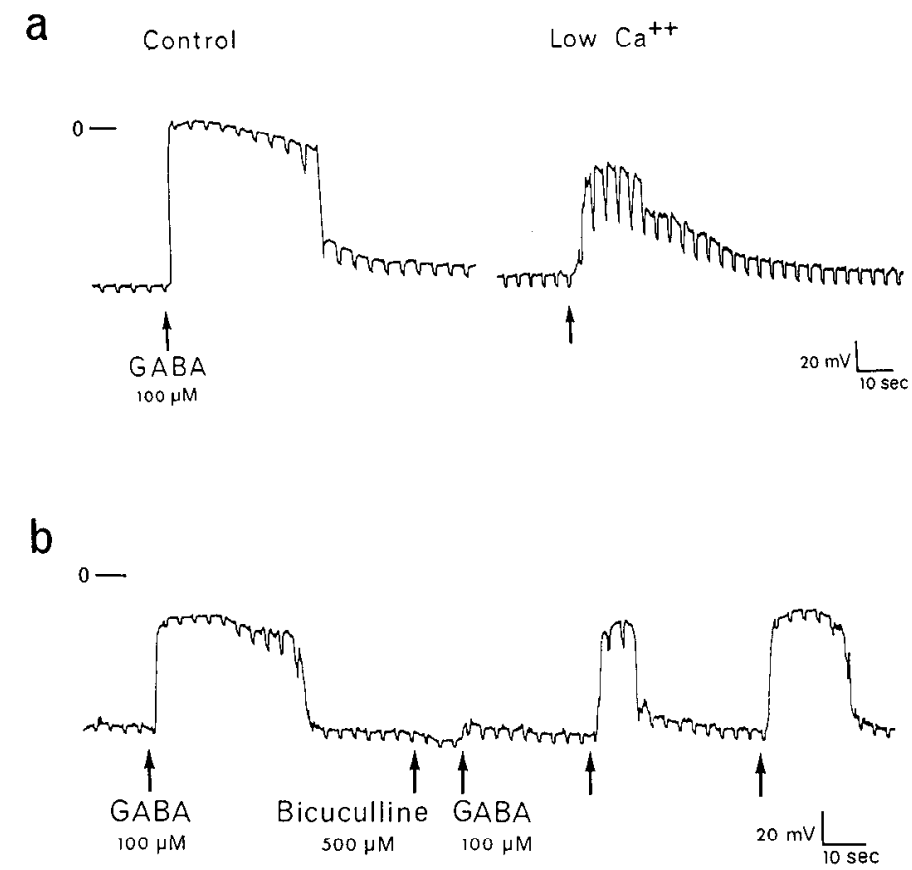

Figure 4. GABA responses of isolated horizontal cells in normal and low $\mathrm{Ca}^{++}$Ringer's solution and the effect of the GABA antagonist bicuculline. $a$, On the left is a control response to GABA. On the right is the response to GABA in Ringer's containing $100 \mu \mathrm{M} \mathrm{CaCl}$; the response is slower and of lower amplitude than in the control solution. See the text for details. $b$, Bicuculline methochloride blocks horizontal cell responses to GABA. On the left is shown a control GABA response. When bicuculline methochloride was applied, followed by a pulse of GABA, no response occurred. After about $30 \mathrm{sec}$, a second application of GABA produced a response of normal amplitude but of attenuated duration; $30 \mathrm{sec}$ later, there was further recovery of the responsiveness to GABA. 
a
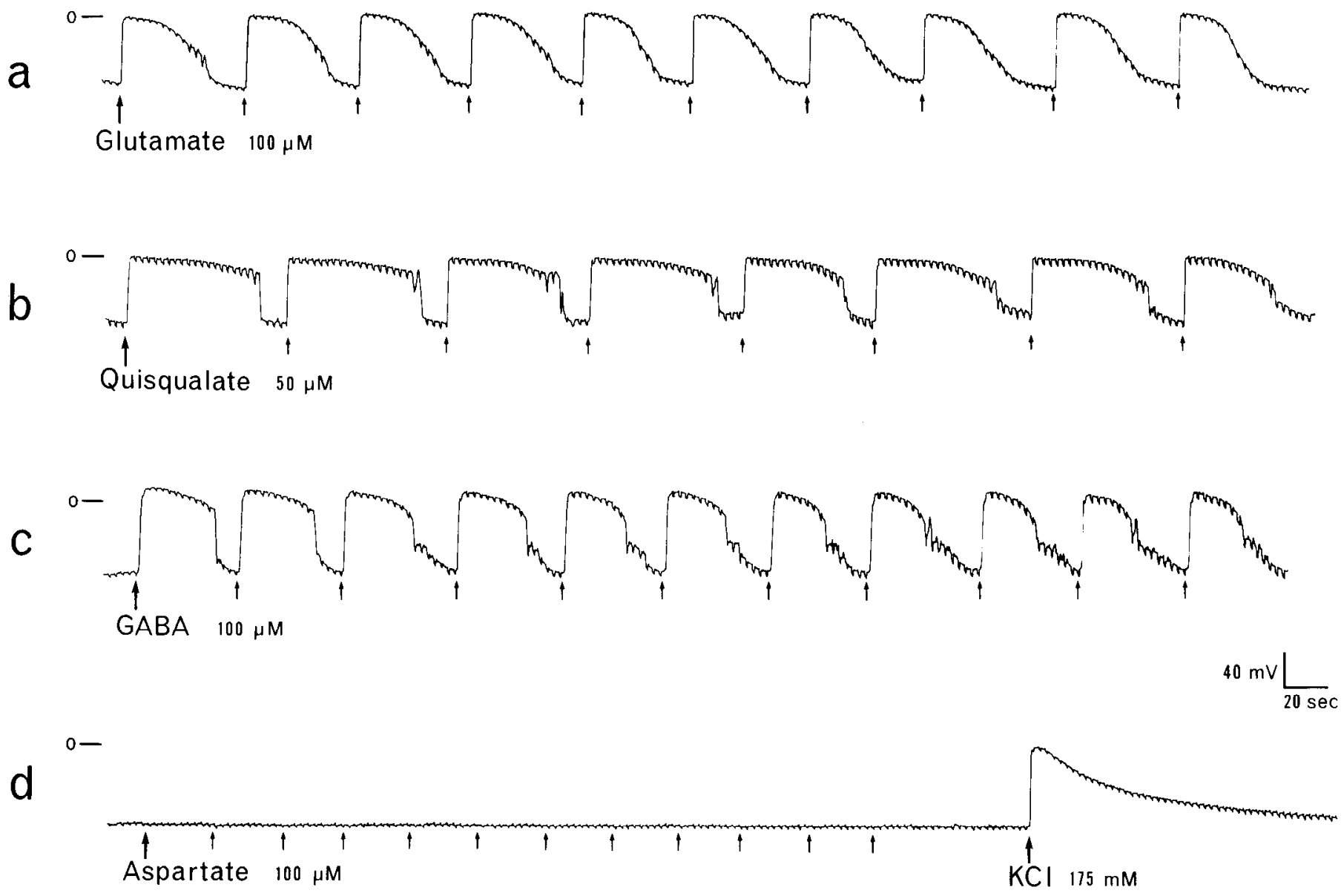

Figure 5. Recordings from isolated horizontal cells during prolonged application of transmitter agents. Drugs were pulsed at regular intervals for a period of about $15 \mathrm{~min}$. These records represent the first $9 \mathrm{~min}$ of drug application. In all cases the form and duration of the intracellular response was relatively constant throughout the experimental run. No desensitization was observed with $(a)$ glutamate, $(b)$ quisqualate, $(c)$ GABA, or kainate (not shown). On the other hand, repeated application of L-aspartate was without effect (d), although the cell was rapidly depolarized by a pulse of $\mathrm{KCl}$.

duration was elicited; $30 \mathrm{sec}$ later the response to GABA increased in amplitude and duration, and soon thereafter it recovered completely. It is noteworthy that, although bicuculline did occasionally block the action of L-glutamate, it was very much less effective. For example, pulse applications of 200 to $500 \mu \mathrm{M}$ bicuculline completely blocked the response to subsequent application of $100 \mu \mathrm{M}$ GABA in 8 of 11 cells tested, whereas it blocked the response to $100 \mu \mathrm{M}$ glutamate in only 1 of 12 cells. Thus, it seems likely that glutamate and GABA interact with distinct postsynaptic receptors on the skate horizontal cells, despite similarities in the cells' reactions to the two agents.

Receptor desensitization and neurotransmitter toxicity. We noted previously that vertebrate photoreceptors continually release an excitatory transmitter in darkness, thereby maintaining postsynaptic elements in a depolarized state. A possible consequence of this prolonged activity could be a desensitization of the second-order cell; i.e., repeated saturation of receptor sites could result in a significant reduction in its responsiveness to the endogenous transmitter (Katz and Thesleff, 1957; Takeuchi and Takeuchi, 1964; Fagni et al., 1983). However, results obtained with prolonged, repeated application of depolarizing agents suggest otherwise. Figure $5 a$ shows that repetitive pulses of $100 \mu \mathrm{M}$ L-glutamate over a 10 -min period consistently produced responses of similar amplitude, duration, and kinetics. Other depolarizing agents (GABA and quisqualate) gave comparable results (Figure 5, $b$ and $c$ ), as did kainate (not shown); however, repeated applications of $500 \mu \mathrm{M}$ L-aspartate had no effect whatever (Fig. 5d).
We observed another phenomenon as a result of prolonged application of KA and quisqualate. After $15 \mathrm{~min}$ of repeated pulses to either of these drugs, the horizontal cells changed morphologically; the larger dendritic processes partially retracted, the fine processes were reduced in number, and numerous excrescences appeared on the cell surface as a result of bubble-like outpockets of cell membrane (Fig. 6). The cellular irregularities did not seem to affect the cells' response to drugs. It is of interest that few or no structural changes were seen after equivalent doses of GABA and L-glutamate, nor did any of the drugs alter the appearance of bipolar cells (Fig. 6b).

\section{Intracellular responses of bipolar cells}

The results to be described are based on intracellular recordings from 75 isolated bipolar cells; their resting potentials ranged from -30 to $-80 \mathrm{mV}$, although in the majority of cases $(60 \%)$ the resting potentials were between -50 and $-80 \mathrm{mV}$ (Fig. 7a). Test agents, delivered in concentrations of 10 to 500 $\mu \mathrm{M}$, included L-glutamate, L-aspartate, quisqualate, KA, GABA, and muscimol. Of these agents, GABA and/or muscimol caused effects on virtually all cells tested, L-glutamate and/or its analogues caused effects on a minority of cells $(28 \%)$, and Laspartate was without effect. Unlike the situation with horizontal cells, GABA and L-glutamate produced strikingly different results on bipolar cells. As shown in Figure $7 b$, L-glutamate and $\mathrm{KA}$, when effective, always produced graded depolarizations of up to $30 \mathrm{mV}$, with KA the more potent agent. The depolarization induced by L-glutamate or its analogues was always accom- 


\section{Control}
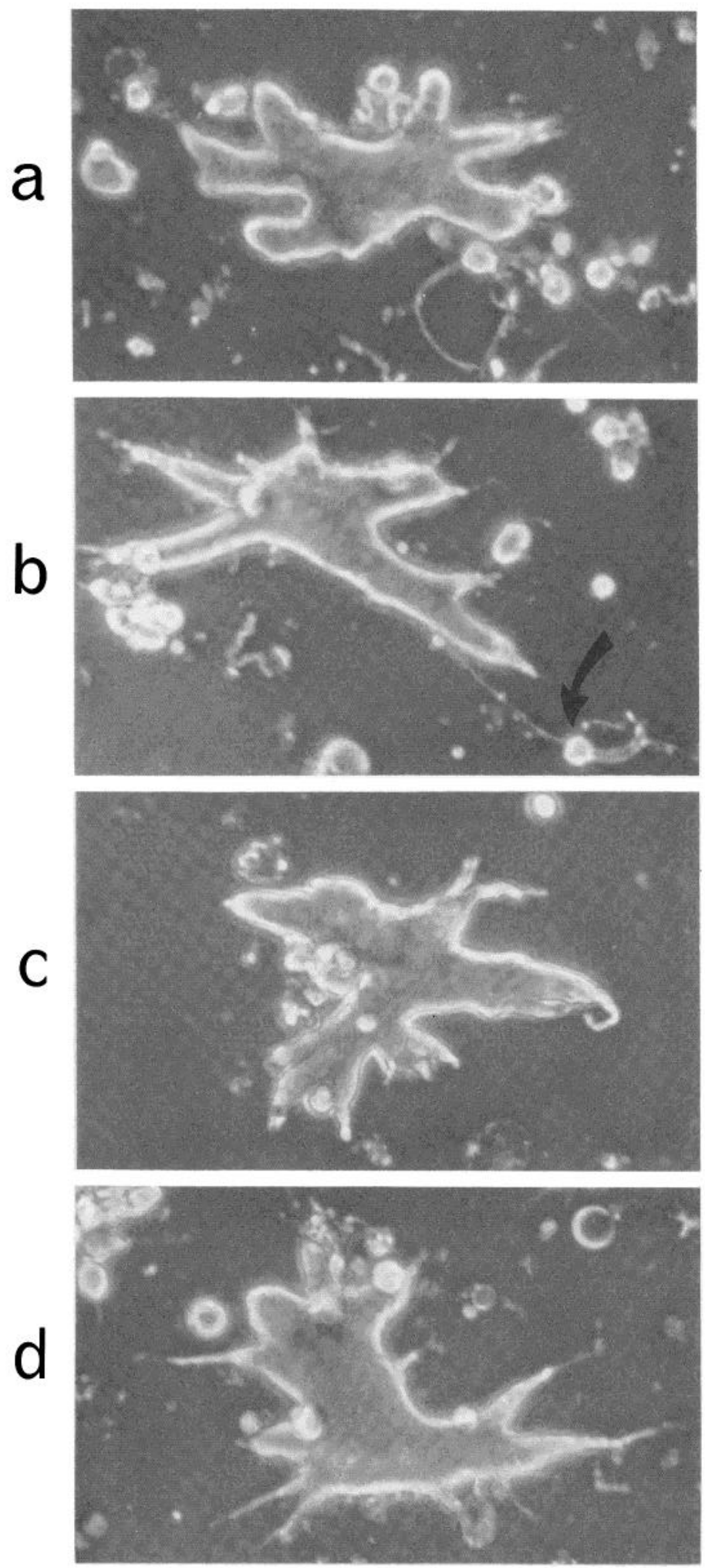

\section{Drug}
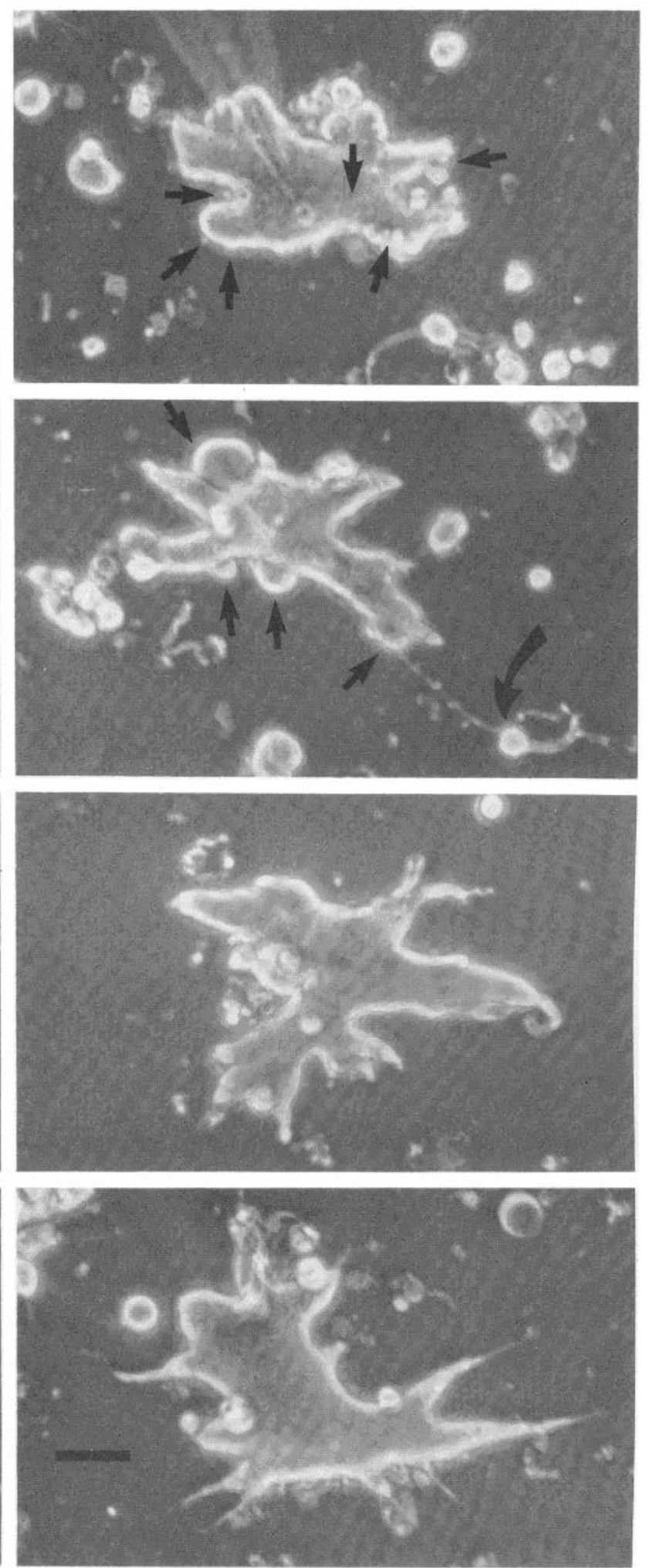

Figure 6. Morphological changes induced in horizontal cells following long-term application (15 min) of test agents. In the left column are shown cells before exposure, and on the right are the same cells after exposure to the drugs. After the cell in $a$ was presented with pulses of 50 $\mu \mathrm{M} \mathrm{KA}$, the major processes were seen to retract and numerous small bubbles (arrows) appeared over the surface of the cell, giving it a mottled or stippled appearance. A microelectrode can be seen impaling this cell during kainate application. The cell in $b$ was exposed to $50 \mu \mathrm{M}$ quisqualate, and, like the kainate-exposed cell, the large processes were retracted. In addition, most fine processes were lost, and outpockets of cytoplasm appeared (arrows). Also shown in $b$ is a bipolar cell (large arrow) which remained unchanged after quisqualate exposure. The cell in $c$ was exposed to pulses of $100 \mu \mathrm{M}$ glutamate, while $100 \mu \mathrm{M}$ GABA was applied to the cell in $d$; the morphology of both cells remained unchanged. The calibration bar is $20 \mu \mathrm{m}$. 

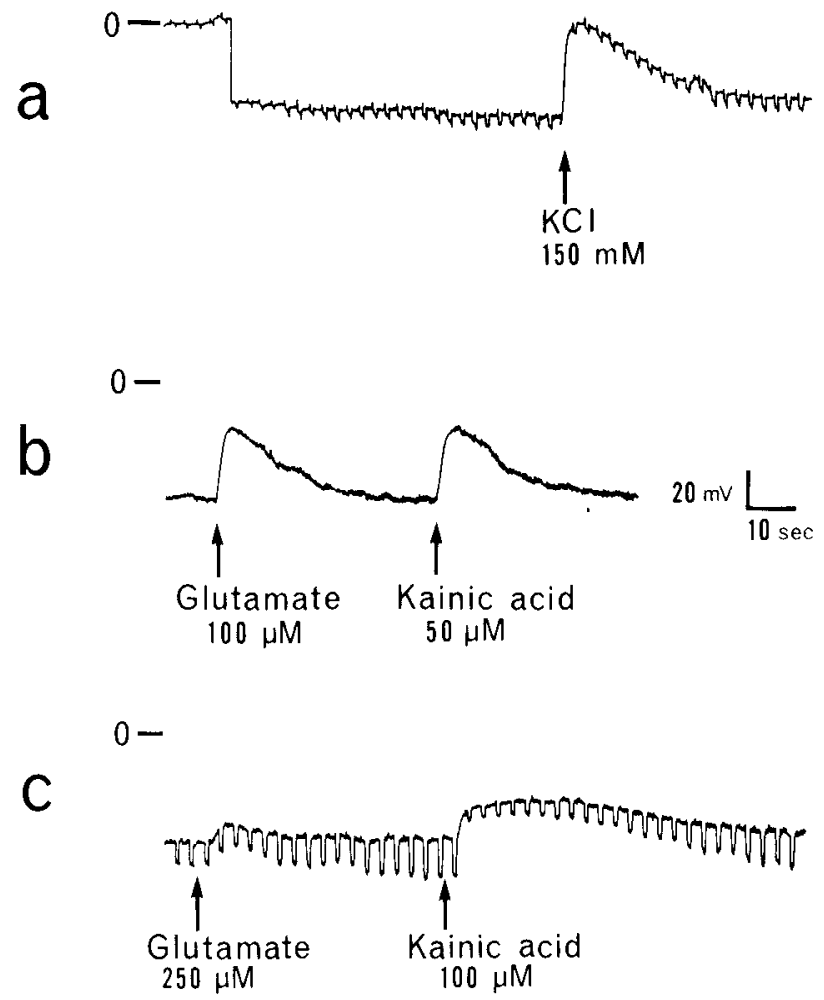

Figure 7. Intracellular recordings from skate bipolar cells. $a$, Typical intracellular recording immediately after penetration and a depolarizing response to $\mathrm{KCl}$. In $b$ and $c$ are shown the responses of bipolar cells to L-glutamate and kainate. In $b$ input resistance was not measured, but these agents typically decreased input resistance, as seen in $c$.

panied by a decrease in membrane resistance (Fig. 7c), and there was never a hint in any of these recordings of voltagesensitive events. The responses to GABA, on the other hand, were more variable, with differences observed in polarity as well as amplitude (Fig. $8, a$ to $c$ ). In Figure $8 a$, for example, the resting potential of the cell was about $-75 \mathrm{mV}$, and GABA (100 $\mu \mathrm{M})$ produced a $20-\mathrm{mV}$ depolarization with a concomitant decrease in input resistance. However, a hyperpolarizing response was elicited (Fig. 8b) when an equivalent pulse of GABA was applied to a cell with a resting potential of $-50 \mathrm{mV}$; but again the input resistance decreased during the initial phase of the response. Lastly, the recording in Figure $8 c$ is from a cell with a resting potential of $-65 \mathrm{mV}$ that showed no change in membrane potential, despite a dramatic decrease in input resistance to GABA. Of the 60 bipolar cells tested for GABA sensitivity, 44 hyperpolarized, 8 depolarized, and 8 remained unchanged; however, all showed a decrease in input resistance, i.e., a conductance increase, in response to the drug. The foregoing suggests that the variability in the response to GABA may be a function of the cell's resting potential and that the reversal potential for the GABA response is approximately -65 $\mathrm{mV}$, probably close to the chloride equilibrium potential for these cells. Moreover, results not shown indicate that the effects of GABA are mediated by membrane receptors and are not due to a nonspecific action on the cell membrane. Both GABA and its agonist muscimol produced membrane hyperpolarizations, but the response to either drug could be blocked by bicuculline.

\section{Discussion}

The results of the present study on skate horizontal cells are similar in a number of respects to those obtained previously with isolated horizontal cells of the carp (Lasater and Dowling, 1982). In particular, the long-lasting responses to L-glutamate and its analogues (Fig. 2) are typical of the findings reported in the earlier study. In both cases, there appear to be two major components to the glutamate response (Fig. $3 a$ ): an initial $\mathrm{Ca}^{++}$. insensitive depolarization and a prolonged regenerative component attributable to a voltage-sensitive $\mathrm{Ca}^{++}$influx (cf. Johnston and Lam, 1981; Tachibana, 1981; Lasater and Dowling, 1982; Shingai and Christensen, 1983a). It is also likely that other voltage-dependent currents are present in these cells and that the overall response properties are determined by the transmembrane fluxes of several ionic species (Tachibana, 1981).

Also noteworthy is the fact that in both carp and skate, the isolated horizontal cells were almost entirely unresponsive to $\mathbf{L}$-aspartate and its analogues and to D-glutamate. In the central nervous system, neurons responsive to excitatory amino acids usually exhibit sensitivity to both glutamate and aspartate, and in varying degree to both the D- and L-isomers. Furthermore, although high concentrations of $\mathrm{L}$-aspartate may occasionally induce depolarizing responses in skate horizontal cells (Fig. $3 b$ ), it appears that the glutamate receptors in these cells are extraordinarily ligand-specific. The ineffectiveness of agents that typically block the action of glutamate, e.g, $\alpha$-methyl glutamate and glutamic acid diethyl ester, is consistent with this view.

Perhaps the most striking difference between the results obtained in carp and those from skate relates to the effects of GABA. In isolated retinal preparations, the addition of GABA to the bathing solution causes the cone-driven horizontal cells of carp and goldfish to hyperpolarize (Murakami et al., 1972; Wu and Dowling, 1980), whereas the drug depolarizes the roddriven cells of the skate retina (Cervetto and MacNichol, 1972). It would have been of particular interest (although not unique, cf. Blankenship et al., 1971) to find that GABA elicits responses of opposite polarity as a consequence of membrane receptors

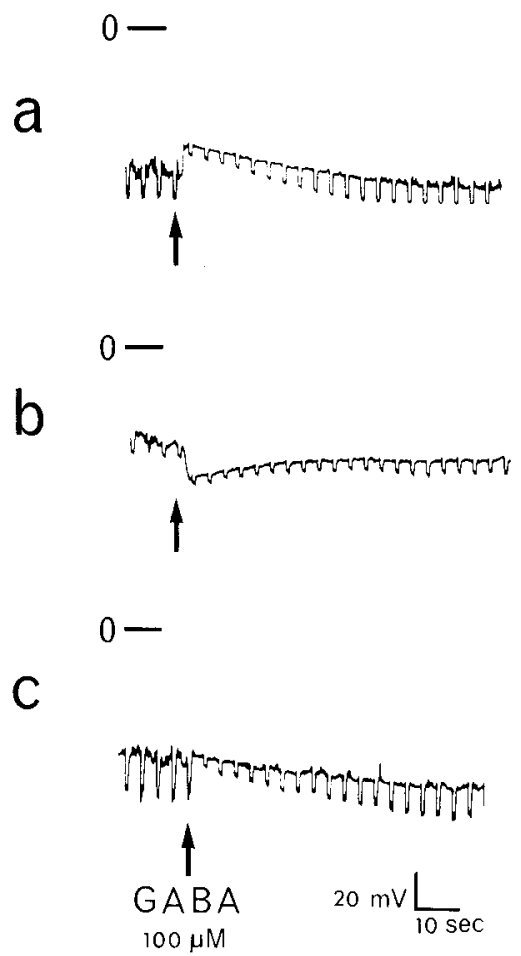

Figure 8. Effects of GABA on isolated bipolar cells. GABA either depolarized or hyperpolarized isolated bipolar cells, depending on the resting membrane potential. In $a$, cells with a high resting potential $(-75 \mathrm{mV})$ were depolarized by GABA, whereas in $b$, cells with a low resting potential of $-50 \mathrm{mV}$ were hyperpolarized. In all cases the GABA response was accompanied by a decrease in input resistance (i.e., a conductance increase) even if no change in membrane potential occurred $(c)$. See the text for details. 
that control different ionic channels in the two kinds of horizontal cell. But this is clearly not the case. In the cyprinid, there is no evidence that GABA affects directly the permeability of the horizontal cell membrane; the GABA response is abolished when $\mathrm{Co}^{++}$is applied to block transmission between receptors and second-order neurons (Wu and Dowling, 1980), and GABA is without effect on the membrane potential of isolated carp horizontal cells in culture (Lasater and Dowling, 1982).

In skate, on the other hand, the GABA effect observed in situ occurs also with isolated horizontal cells (Fig. 2). In addition, the fact that the GABA response can be blocked by bicuculline (Fig. $4 b$ ) is further evidence that the drug effect is mediated by GABA-sensitive membrane receptors of horizontal cells. In view of these findings, it was surprising that the GABA agonist muscimol failed to elicit a change in membrane potential when applied to isolated horizontal cells. To our knowledge, this is the first instance of a bicuculline-sensitive GABA receptor that is unresponsive to muscimol (Johnston, 1976), and it suggests that the GABA receptors on skate horizontal cells may be structurally different from those in the CNS. Alternatively, changes in receptor configuration may have been induced by the digestive enzymes used in the cell isolation procedure.

We have yet to explore in detail the ionic basis of the horizontal cell response to GABA. However, it resembles strongly the response to L-glutamate, and it would appear that there is a $\mathrm{Ca}^{++}$conductance increase following GABA application which usually results in a regenerative response. A similar situation appears to exist in isolated catfish horizontal cells where it was found that L-glutamate caused a nonspecific increase in the conductance to several ions which ultimately resulted in action potential generation (Shingai and Christensen, $1983 \mathrm{~b})$. The results obtained with isolated bipolar cells (Figs. 7 and 8) suggest that in skate these elements also contain membrane receptors for GABA which probably control the gating of chloride ions. On this view, GABA behaves as a typical inhibitory neurotransmitter; i.e., the concomitant increase in conductance associated with the GABA-induced change in membrane potential results from the opening of $\mathrm{C1}^{-}$ channels (cf. Roberts et al., 1976).

In view of the evidence for GABA-sensitive neurons in the distal retina of the skate, it is important to consider the source of the GABAergic input to these cells. Brunken et al. (1983), employing an antibody to the GABA-specific enzyme, glutamic acid decarboxylase (GAD), have demonstrated recently that the interplexiform cells are stained with the fluorescein isothiocyanate-conjugated antibody. Moreover, there is good evidence in skate that mechanisms exist for the selective uptake of GABA into Müller cells, where it is probably degraded (Lam, 1975).

Another interesting feature of the horizontal cell responses to test agents concerns its resistance to desensitization; the cells continued to depolarize maximally to pulses of agonists even after prolonged, repeated application of the drugs (Fig. 5). Desensitization appears to be a common property of the synaptic mechanism of the neuromuscular junction, e.g., the cholinergic motor end plate (Katz and Thesleff, 1957) and the glutaminergic synapse of crayfish muscle (Takeuchi and Takeuchi, 1964), and it has been suggested that the effect is associated with a decrease in the number of available binding sites or changes in receptor-channel coupling (cf. Heidmann and Changeux, 1978). However, interneuronal synapses seem generally to be more resistant to desensitization; no evidence of the phenomenon was seen at amino acid-sensitive synapses of the cerebral cortex (Krnjevic and Phyllis, 1963) and spinal cord (Curtis et al., 1960), although a rapid, reversible desensitization of pyramidal and granule cells in the rat hippocampus has been reported (Fagni et al., 1983). It seems likely that in such cases a low affinity of the receptor, combined with effective inactivating mechanisms, enables the postsynaptic elements to recover fully from prolonged exposure to agonists. This is clearly a desirable situation for second-order cells in the vertehrate retina, which are exposed continuously in the dark to the discharge of photoreceptor transmitter (Ripps et al., 1976). Also of interest was the finding that while the horizontal cells continued to be responsive to repeated applications of agonist, some of the agents produced severe morphological changes; e.g., after kainate or quisqualate, the cells retracted their major processes, the finer processes deteriorated, and blebs were formed on the cell surface. These reactions may be related to some of the neurotoxic effects induced by excitatory amino acids (McGeer et al., 1978) or to the cellular changes reported by Yazulla and Kleinschmidt (1980) following intraocular injection of kainate.

Finally, it is important to consider what effects the isolation procedure may have on the structure and distribution of postsynaptic receptor sites on isolated cells. Although the cells resemble morphologically their appearance in situ and seem to be functionally viable, the fine terminal processes of horizontal cells are no longer visible after several hours in culture. It appears that the synaptic membrane of the horizontal cell processes has been incorporated into the larger dendritic branches, and it is uncertain what effect this may have on cellular physiology. While it is likely that the reported drug effects are mediated by the activation of membrane receptors, we cannot rule out the possibility that some receptor sites are lost in the course of isolation or structurally altered in the process. One reason for concern in this regard is the surprising inconsistency of the results obtained from bipolar cells with Lglutamate and its analogues. Only 28 percent of the bipolar cells tested responded to $\mathbf{L}$-glutamate or its analogues (Fig. $7 b$ ). However, there is abundant evidence-in addition to the present data on horizontal cells-in support of the view that $L$ glutamate or a closely related compound (Cervetto and MacNichol, 1972; Murakami et al., 1972; Dowling and Ripps, 1973; Kancko and Shimazaki, 1976; Wu and Dowling, 1978; Marc and Lam, 1981) is a photoreceptor transmitter. Moreover, recent studies have shown that the structural analogues of glutamate, i.e., kainate and 2-amino-4-phosphono-butyrate (APB), alter the membrane potential of bipolar cells in the elasmobranch (dogfish) retina; the former hyperpolarizes the on-center bipolar cell, whereas APB produces a depolarization after cobalt blockade of on-center cell activity (Shiells et al., 1981). Therefore, there is the possibility that the integrity of the glutamate receptors on the isolated bipolar cells has been altered during cell dissociation. Further studies, employing a variety of isolation techniques, may be required to resolve this question.

\section{References}

Ariel, M., E. M. Lasater, S. C. Mangel, and J. E. Dowling (1983) On the sensitivity of $\mathrm{H} 1$ horizontal cells of the carp retina to glutamate, aspartate and their agonists. Brain Res. 295: 179-183.

Blankenship, J. E., H. Wachtel, and E. R. Kandel (1971) Ionic mechanisms of excitatory, inhibitory, and dual synaptic actions mediated by an identified interneuron in abdominal ganglion of Aplysia. J. Neurophysiol. 34: 76-92.

Brunken W., H. Karten, and P. Witkovsky (1983) Immunocytochemical studies in elasmobranch retina. Invest. Ophthalmol. Vis. Sci. 24 (Suppl.): 65.

Cervetto, L., and E. F. MacNichol, Jr. (1971) Pharmacology of horizontal cells in the isolated perfused skate retina. Biol. Bull. 141: 381.

Cervetto, L., and E. F. MacNichol, Jr. (1972) Inactivation of horizontal cells in turtle retina by glutamate and aspartate. Science 178: $767-$ 768.

Curtis, D. R., J. W. Phyllis, and J. C. Watkins (1960) The chemical excitation of spinal neurons by certain acidic amino acids. J. Physiol. (Lond.) 150: 656-682. 
Dowling, J. E., and H. Ripps (1970) Visual adaptation in the retina of the skate. J. Gen. Physiol. 56: 491-520.

Dowling, J. E., and H. Ripps (1971) S-potentials in the skate retina. Intracellular recordings during light and dark adaptation. J. Gen. Physiol. 58: 163-189.

Dowling, J. E., and H. Ripps (1972) Effects of $\mathrm{Mg}^{2+}$ on skate horizontal cells: Evidence for release of transmitter from receptors in darkness. Biol. Bull. 143: 458-459.

Dowling, J. E., and H. Ripps (1973) Effect of magnesium on horizontal cells activity in the skate retina. Nature (Lond.) 24: 101-103.

Fagni, L., M. Baudry, and G. Lynch (1983) Desensitization to glutamate does not affect synaptic transmission in rat hippocampal slices. Brain Res. 261: 167-171.

Heidman, T., and J. -P. Changeux (1978) Structural and functional properties of the acetylcholine receptor protein in its purified and membrane-bound states. Annu. Rev. Biochem. 47: 317-357.

Ishida, A. T. (1982) Selective potentiation of retinal horizontal cells responses to L-glutamate by D-aspartate. Comp. Biochem. Physiol. $72 C: 241-247$.

Ishida, A. T., and G. L. Fain (1981) D-Aspartate potentiates the effects of L-glutamate on horizontal cells in goldfish retina. Proc. Natl. Acad. Sci U. S. A. 78: 5890-5894.

Johnston, D., and D. M. K. Lam (1981) Regenerative and passive membrane properties of isolated horizontal cells from a teleost retina. Nature (Lond.) 292: 451-454.

Johnston, G. A. R. (1976) Physiologic pharmacology of GABA and its antagonists in the vertebrate nervous system. In GABA in Nervous System Function, E. Roberts, T. N. Chase, and D. B. Tower, eds., pp. 395-411, Raven Press, New York.

Kaneko, A., and H. Shimazaki (1976) Synaptic transmission from photoreceptors to bipolar and horizontal cells in the carp retina. Cold Spring Harbor Symp. Quant. Biol. 40: 537-546.

Katz, B., and S. 'I'hesleff (1957) A study of the "desensitization" produced by acetylcholine at the motor end-plate. J. Physiol. (Lond.) 138: $63-80$.

Krnjevic, K., and J. W. Phyllis (1963) Iontophoretic studies of neurones in the mammalian cerebral cortex. J. Physiol. (Lond.) 165: 274-304.

Lam, D. M. K. (1975) Synaptic chemistry of identified cells in the vertebrate retina. Cold Spring Harbor Symp. Quant. Biol. 40: 571 579 .

Lasater, E. M., and J. E. Dowling (1982) Carp horizontal cells in culture respond selectively to L-glutamate and its agonists. Proc. Natl. Acad. Sci. U. S. A. 79: 936-940.

Lasater, E. M., K. J. Watling, J. E. Dowling (1983) Vasoactive intestinal peptide induces cAMP accumulation and membrane potential changes in isolated carp horizontal cells. Science 221: 1070-1072.

MacDonald, J. F., and J. M. Wojtowice (1980) 'Two conductance mechanisms activated by applications of $\mathbf{L}$-glutamic, L-aspartic, DLhomocysteic, $N$-methyl-D-aspartic, and DL-kainic acids to cultured mammalian central neurones. Can. J. Physiol. Pharmacol. 58: 13931397.

MacDonald, J. F., and J. M. Wojtowicz (1982) The effects of L- glutamate and its analogues upon the membrane conductance of central murine neurones in culture. Can. J. Physiol. Pharmacol. 60: 282-296.

Marc, R. E., and D. M. K. Lam (1981) Uptake of aspartic and glutamic acid by photoreceptors in the goldfish retina. Proc. Natl. Acad. Sci. U. S. A. 78: 7185-7189.

McGeer, E. G., J. W. Olney, and P. L. McGeer (1978) Kainic Acid as a Tool in Neurobiology, Raven Press, New York.

Murakami, M., K. Ohtsu and T. Ohtsuka (1972) Effects of chemicals on receptors and horizontal cells in the retina. J. Physiol. (Lond.) 227: 899-913

Ripps, H., M. Shakib, and E. D. MacDonald (1974) Turnover of synaptic vesicles in photoreceptor terminals of the skate. Biol. Bull. 147: 495.

Ripps, H., M. Shakib, and E. D. MacDonald (1976) Peroxidase uptake by photoreceptor terminals of the skate retina. J. Cell Biol. 70: 8696.

Roberts, E., T. N. Chase, and D. B. Tower (1976) GABA in Nervous System Function, Raven Press, New York.

Shiells, R. A., G. Falk, and S. Neghshineh (1981) Action of glutamate and aspartate analogues on rod horizontal and bipolar cells. Nature (Lond.) 29: 592-594.

Shingai, R., and B. N. Christensen (1983a) Ionic mechanisms underlying the action of putative transmitters on enzymatically dissociated horizontal cells. Soc. Neurosci. Abstr. 9: 263.

Shingai, R., and B. N. Christensen (1983b) Sodium and calcium currents measured in isolated catfish horizontal cells under voltage clamp. Neuroscience 10:893-897.

Szamier, R. B., and H. Ripps (1983) The visual cells of the skate retina: Structure, histochemistry, and disc-shedding properties. J. Comp. Neurol. 215: 51-62.

Tachibana, M. (1981) Membrane properties of solitary horizontal cells isolated from goldfish retina. J. Physiol (Lond.) 321: 141-161.

Takeuchi, A., and N. Takeuchi (1964) The effect on crayfish muscle of iontophoretically-applied glutamate. J. Physiol. (Lond.) 170: 296317.

Trifonov, Y. A. (1968) Study of synaptic transmission between the photoreceptor and the horizontal cell using electrical stimulation of the retina. Biofizika 13: 809-817.

Tunnicliff, G. (1975) Glutamate uptake by chick retina. Biochem. J. 15: $297-299$.

Wojtowicz, J. M., M. Gysen, and J. F. MacDonald (1981) Multiple reversal potentials for responses to $\mathrm{L}$-glutamic acid. Brain Res. 21: 195-200.

Wu, S., and J. E. Dowling (1978) L-Aspartate: Evidence for a role in cone photoreceptor synaptic transmission in the carp retina. Proc. Natl. Acad. Sci. U. S. A. 75: 5202-5209.

Wu, S. M., and J. E. Dowling (1980) Effects of GABA and glycine on the distal cells of the cyprinid retina. Brain Res. 199: 401-414.

Yazulla, S., and J. Kleinschmidt (1980) The effects of intraocular injections of kainic acid on the synaptic organization of the goldfish retina. Brain Res. 182: 287-301 